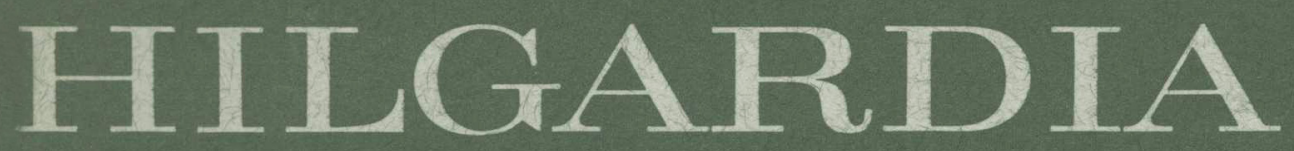

A JOURNAL OF AGRICULTURAL SCIENCE PUBLISHED BY THE CALIFORNIA AGRICULTURAL EXPERIMENT STATION

Volume 34, Number 2 March, 1963

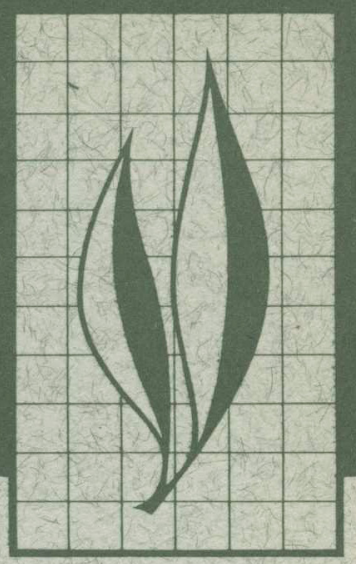

\title{
Studies on Lipids in Some Homopterous Insects
}

Frank E. Strong 


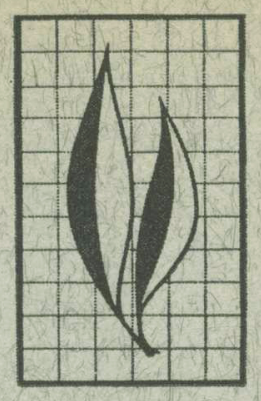

There is little information available on the occurrence of lipids in aphids or other sucking insects, and little is known of the role of lipids in aphid nutrition. The purpose of the present investigation was to obtain preliminary information on several phases of these problems. The classes of lipids extracted from one aphid, Macrosiphum barri Essig, were separated by column chromatography. The fatty acids in each of these classes as well as in the crude lipid extracts from 20 other species of aphids and six species of leafhoppers were separated by gas-liquid chromatography. Nearly all of the fatty acids in M. barri were in the form of triglycerides, as in other insects that have been studied by previous investigators. The free fatty/acids accounted for only a small percentage of the total quantity of lipids extracted from $M$. barri.

In general, aphids had a high proportion of the fatty acids with a carbon chain length of 14 or less and a low proportion of fatty acids with 18 carbon atoms. The reverse was found for the leafhoppers analyzed. The fatty acid composition of an aphid appears to be a species characteristic, not appreciably influenced by the host plant. It changed with the stage of development in some species but not in others. Its possible usefulness in aphid taxonomy is uncertain at present.

Fatty acids were found in the honeydew of two species of aphids. Their relative proportions in the honeydew of the green peach aphid and in the juice of its host suggest that linoleic acid may be required in the diet of that aphid.

THE AUTHOR:

Frank E. Strong is Assistant Professor of Entomology and Assistant Entomologist in the Experiment Station, Davis. 


\section{Studies on Lipids in Some Homopterous Insects ${ }^{1}$}

MoST OF THE STUDIES of lipids extracted by organic solvents from various insects have been made on leaf- or stem-feeding Lepidoptera, Coleoptera, or Diptera. The values of the iodine numbers used to characterize the crude lipids from these insects-ranging approximately from 100 to 140 -indicate that, although the variation is great, the degree of unsaturation is, in general, high.

Gilmour (1961) and Hilditch (1956) have reviewed the occurrence of lipids in insects. The first report on the lipid composition of an aphid was that of Timon-David (1928), who demonstrated that lipids from gall-forming aphids of the genus Pemphigus have the remarkably low iodine number of 1.5 and contain a high proportion of the volatile, short-chain fatty acids.

Lipids in insects usually occur in the form of glycerides. Giral (1946), however, noted the virtual absence of glycerides in an orthopteron, Sphenarium purpurascens Charpentier. Wren and Mitchell (1959) made a definitive study on the separation of various lipid classes in Drosophila spp. and identified several phosphatides and other compound lipids.

Friend (1958) and House (1961) reviewed the literature on the nutritional requirements of insects for specific lipids. To date all insects studied showed a requirement for a sterol (Gilmour, 1961), though not necessarily for the same specific sterol (Levinson and Bergmann, 1957). When critically studied, many insects showed also a requirement for a polyunsaturated fatty acid. Thus, Dadd (1960) reported that linoleic acid was essential for the development of Locusta migratoria Linnaeus and Schistocerca gregaria (Forsk.). Fraenkel and Blewett (1946) found that either linoleic acid or arachidonic acid could satisfy the requirement of three species of Ephestia for a polyunsaturated fatty acid. Classically, the inability of an animal to synthesize, either in vitro or in vivo, a compound found in its body carries the connotation that this compound is necessary in the animal's diet. Thus, the inability of Locusta migratoria to synthesize in vitro appreciable amounts of polyunsaturated fatty acids (Tietz, 1961) supports Dadd's findings. Zebe and McShan (1959) reported that Prodenia eridania (Cramer) failed to incorporate $\mathrm{C}^{14}$-acetate in significant amounts into polyunsaturated fatty acids in vitro. Van Handel and Lum (1961) obtained the same results in vivo with Aedes sollicitans (Walker) and A. taeniorhynchus (Wiedemann).

No reports on the lipid requirements of aphids have been found. Until Mittler and Dadd (1962) developed a method for feeding aphids through a membrane, no one succeeded in feeding aphids artificially for extended periods. 
The direct analysis of phloem sap would provide some information on an aphid's diet-depending, of course, on the completeness of the analysis. Mittler (1953 and 1958) and von Dehn (1961) identified free amino acids and some sugars in the phloem sap exuded through aphid stylets severed in situ by the method of Kennedy and Mittler (1953). However, the minute volumes of sap collected by this method do not permit chemical manipulations other than direct chromatographic analysis. It is often assumed that aphids feed exclusively on phloem sap, but Esau, Namba, and Rasa (1961) demonstrated that this is not the case for Myzus persicae (Sulzer), the green peach aphid. Therefore, the determination of an aphid's diet would be somewhat tentative even if a complete analysis of phloem sap were possible.

In an attempt to circumvent the lack of information on the food of aphids, Maltais and Auclair (1952), Mittler (1953), and Lamb (1959) analyzed honeydew; Mittler (1953 and 1958) and Waterhouse (1957) compared such analyses with the sap of the host plant. If such comparisons are valid, even in part, then a compound present in greater abundance in the sap than in the honeydew might be regarded as important if not essential in the aphid's diet.

None of these partial chemical analyses of honeydew indicated the presence of lipids. This circumstance, together with the paucity of information on the occurrence of lipids in aphids, suggested the need for a study on the subject. The purpose of the present investigation is simply to obtain facts which may be used for further, more definitive studies.

\section{MATERIALS AND METHODS}

Unless otherwise stated, the aphids analyzed were apterae in various stages. Winged adults, parasitized individuals, unwanted species, debris, etc., were removed from the collections by hand. The remaining aphids were placed in vials containing chloroform and methanol $(1: 1 \mathrm{v} / \mathrm{v})$. The lipids were extracted with this solvent mixture, after the method of Folch, Lees, and SloaneStanley (1957). In some cases the aphids were collected dry, lyophilized, and stored at $-10^{\circ} \mathrm{F}$ under a nitrogen atmosphere until analyzed. With leafhoppers, only the adults were analyzed. Generally, $50 \mathrm{mg}$ of the insects were sufficient for an analysis.

Fractionation. Both a silicic acid column $^{2}$ and a Florisil $^{3}$ column were used to fractionate the crude lipid extract from one aphid, Macrosiphum barri Essig. First a portion of the crude lipid extract was placed on the silicic acid column and the neutral lipids were eluted with chloroform. The phospholipids retained on the column were then eluted with dry methanol (Van Handel, 1959). The phospholipids were weighed but not analyzed further. A second portion of the crude lipid extract was placed on a 12-gm deactivated Florisil column, $1.2 \mathrm{~cm} \times 40 \mathrm{~cm}$, where the lipids were eluted by the method of Carroll (1961) with the solvents indicated in figure 1. Eighty-three 5-m] fractions were collected, the solvents were evaporated in vacuo, and the eluted solutes were determined gravimetrically.

Preparation of Methyl Esters. For analyses by gas-liquid chromatography (GLC), the fatty acids extracted from

\footnotetext{
${ }^{2}$ A slurry in chloroform of $0.5 \mathrm{gm}$ silicic acid (suitable for chromatographic purposes, Mallinckrodt Chemical Works) plus $0.5 \mathrm{gm}$ Hyflo Super-Cell (Johns-Manville Corp.) made a column $0.75 \mathrm{~cm} \times 10 \mathrm{~cm}$.

${ }^{3}$ Florisil is the trade name of a white, granular mixture of magnesium oxide 15.5 per cent, silicon dioxide 84.0 per cent, and sodium sulfate 0.5 per cent, made by the Floridin Company, Tallahassee, Florida.
} 
TABLE 1

CALIBRATION OF THE HYDROGEN FLAME IONIZATION

DETECTOR: RESPONSE OF INSTRUMENT TO FATTY ACID METHYL ESTERS IN STANDARD MIXTURE $C$ (Metabolism Study Section, N.I.H.)

\begin{tabular}{|c|c|c|c|}
\hline \multirow{2}{*}{ Fatty acid } & \multicolumn{2}{|c|}{ Composition of Mixture $C$} & \multirow{2}{*}{$\begin{array}{c}\text { Response } \\
\text { of } \\
\text { instrument }\end{array}$} \\
\hline & As published & $\begin{array}{l}\text { As determined } \\
\text { by instrument* }\end{array}$ & \\
\hline & per cent by weight & per cent & per cent \\
\hline $\mathbf{C}_{\mathbf{8}} \ldots$ & 1.55 & 0.78 & 50.32 \\
\hline $\mathrm{C}_{10} \ldots$ & 2.99 & 2.08 & 69.56 \\
\hline $\mathrm{C}_{12} \ldots \ldots$ & 5.96 & 5.03 & 84.39 \\
\hline $\mathrm{C}_{14} \ldots$ & 11.96 & 11.29 & 94.40 \\
\hline $\mathrm{C}_{16} \ldots$ & 19.41 & 19.42 & 100.05 \\
\hline $\mathrm{C}_{18} \ldots$ & 24.91 & 26.20 & 105.18 \\
\hline $\mathrm{C}_{20} \ldots$ & 33.19 & 35.08 & 105.69 \\
\hline
\end{tabular}

* Calculated from the relative retention times and the heights of the peaks.

all aphids were first converted to their methyl esters, as follows: The crude lipid extract was washed twice with water to remove the methanol and the water-soluble impurities. The chloroform layer was dried over $\mathrm{MgSO}_{4}$, filtered, and evaporated to dryness at $60^{\circ} \mathrm{C}$ in a rotating evaporator. Two $\mathrm{ml}$ of dry methanol, redistilled over $\mathrm{KOH}$ and zine dust, were added and brought to a gentle boil, to dissolve the lipid material. Next, $0.2 \mathrm{ml}$ of $0.1 \mathrm{~N}$ sodium methylate in dry methanol was added, the mixture was gently boiled for one minute, after which $15 \mathrm{ml}$ of water were added, plus sufficient $0.1 \mathrm{~N} \mathrm{HCl}$ to adjust the $\mathrm{pH}$ to about 6.8. Esters were extracted three times from the aqueous solution with $5-\mathrm{ml}$ portions of diethyl ether. The ether extracts were combined, dried for 30 minutes over $\mathrm{MgSO}_{4}$, and filtered directly into a KadurnaDanish flask equipped with a Schneider column. Ether was removed at $45-50^{\circ}$ C until the volume was reduced to about $100 \mu \mathrm{l}$, and $0.3-$ to $1.2-\mu \mathrm{l}$ aliquots of this were injected onto the GLC column, to separate the methyl esters.
Gas-Liquid Chromatography. The liquid phase of the GLC column consisted of polyethylene glycol adipate plus 85 per cent phosphoric acid and was coated on 60/80-mesh Chromosorb $\mathrm{W}^{\mathrm{s}}$. This was packed into eighth-inch stainless steel tubing, 5 feet long. The carrier gas was water-pumped nitrogen, and the instrument was fitted with a hydrogen flame ionization detector. Originally the polyethylene glycol adipate was 25 per cent of the column, by weight, and the phosphoric acid was 2 per cent, but as the column was operated for several months at $203-213^{\circ}$ $\mathrm{C}$, or near the upper limits of the liquid phase, the percentage of the liquid phase decreased appreciably with time. As a result, the exact percentage of the liquid phase for any given analysis was not known.

The GLC apparatus was calibrated with standard mixtures of fatty acid methyl esters. $^{.}$Standard Mixture $C$ contains a homologous series of seven methyl esters, from $\mathrm{C}_{8}{ }^{7}$ to $\mathrm{C}_{20}$, and was used to test the mass sensitivity of the detector. The response was curvilinear

'LAC-2R-446, Cambridge Industries Company, Inc., Cambridge, Mass.

5 Johns-Mansville Corp.

${ }^{8}$ Standard Mixtures $C$ and $D$ were obtained from Dr. W. H. Goldwater, Metabolism Study Section, National Institutes of Health.

${ }^{7} \mathrm{~A}$ shorthand designation is used to indicate the carbon chain length and the degree of unsaturation: $\mathrm{C}_{8}$ is caprylic acid, $\mathrm{C}_{16: 1}$ is palmitoleic, and so forth. 
for the short-chain fatty acids and approximately linear for fatty acids with chain lengths of $\mathrm{C}_{14}$ and longer (table 1). The figures in tables 2 through 10 reflect this nonlinear response. For example, in any given analysis the true amount of $\mathrm{C}_{8}$ was actually 50 per cent greater than that reported. Standard Mixture $D$ was used to test the ability of the column to separate two closely related fatty acid methyl esters. It showed that the resolving power of the column was sufficiently high to give a clean separation of $\mathrm{C}_{16}$ from $\mathrm{C}_{16: 1}$ and of $\mathrm{C}_{18}$ from $\mathrm{C}_{18: 1}$.

The fatty acids present in the lipid extracts were identified by comparing their relative retention times with those of the known standards. The relative amount of any given fatty acid was estimated from the product of the retention time and the peak height. The actual amount could then be calculated on the basis of the percentage response of the detector for that acid, as determined by calibration of the instrument with Standard Mixture $C$.

Samples. Duplicate samples of each extract were analyzed on the GLC column but, for most of the insect collections, duplicate extracts were not prepared. To test the biological variation between collections, duplicate collections of three aphid species were analyzed and the variations obtained for the separate collections of a species were estimated as standard deviations.

Honeydew samples were collected each 24 hours on tared aluminum foil and washed from the foil with tepid water. The aqueous solution was acidified to $\mathrm{pH} 6.0$ and the lipid components were extracted three times with a chloroform:ethanol $(5: 2 \mathrm{v} / \mathrm{v})$ mixture. Acidification and ethanol helped prevent the formation of troublesome emulsions. The chloroform layer was washed twice with water and dried over $\mathrm{MgSO}_{4}$, and the methyl esters were prepared as described above.

Juice expressed at 5,000 pounds per square inch from freshly frozen sugar beet leaves (Beta vulgaris) was centrifuged at $2,000 \mathrm{~g}$ for 30 minutes. Lipids were extracted from the slightly cloudy supernatant, as described for honeydew, and the methyl esters were prepared.

TABLE 2

FATTY ACID COMPOSITION OF APTERAE OF THREE SPECIES OF APHIDS, WITH THE VARIATIONS BETWEEN DUPLICATE OR TRIPLICATE COLLECTIONS EXPRESSED AS STANDARD DEVIATIONS

\begin{tabular}{|c|c|c|c|}
\hline Fatty acid & $\begin{array}{c}\text { Myzus persicae } \\
\text { (Sulzer) from } \\
\text { tomato }\end{array}$ & $\begin{array}{l}\text { Macrosiphum euphor- } \\
\text { biae (Thomas). Pink } \\
\text { form from oxalis, } \\
\text { green and pink } \\
\text { forms from myrtle }\end{array}$ & $\begin{array}{l}\text { Pemphigus bursarius } \\
\text { (Linnaeus) from } \\
\text { lettuce roots and a } \\
\text { black poplar leaf gall }\end{array}$ \\
\hline & per cent & per cent & per cent \\
\hline$\ldots \ldots \ldots \ldots \ldots$ & $\ldots \ldots \ldots$ & $0.68 \pm 0.15$ & $0.65 \pm 0.51$ \\
\hline $\mathrm{C}_{6} \ldots$ & $4.37 \pm 0.89$ & $3.99 \pm 0.61$ & $0.30 \pm 0.02$ \\
\hline $\mathrm{C}_{8} \ldots$ & N.D.* & $0.26 \pm 0.15$ & $9.37 \pm 3.10$ \\
\hline $\mathbf{C}_{\boldsymbol{g}} \ldots \ldots \ldots \ldots \ldots$ & N.D. & $1.59 \pm 0.14$ & N.D. \\
\hline $\mathrm{C}_{10} \ldots \ldots \ldots \ldots$ & $1.41 \pm 0.59$ & $0.26 \pm 0.09$ & $0.24 \pm 0.14$ \\
\hline $\mathrm{C}_{12} \ldots \ldots \ldots \ldots \ldots$ & $1.91 \pm 0.20$ & $5.64 \pm 1.06$ & $3.99 \pm 0.47$ \\
\hline $\mathrm{C}_{14} \ldots$ & $79.03 \pm 3.09$ & $71.59 \pm 2.10$ & $49.39 \pm 4.62$ \\
\hline $\mathbf{C}_{16} \ldots \ldots \ldots \ldots \ldots \ldots$ & $4.05 \pm 1.32$ & $3.34 \pm 0.67$ & $21.87 \pm 3.47$ \\
\hline $\mathrm{C}_{16}: 1 \ldots \ldots \ldots \ldots$ & $0.33 \pm 0.16$ & $0.59 \pm 0.21$ & $0.19 \pm 0.11$ \\
\hline $\mathbf{C}_{18} \ldots$ & $3.42 \pm 1.25$ & $1.66 \pm 0.23$ & $4.26 \pm 0.97$ \\
\hline$C_{18}: \ldots \ldots \ldots \ldots$ & $2.70 \pm 0.34$ & $2.79 \pm 0.45$ & $2.22 \pm 0.22$ \\
\hline $\mathrm{C}_{18: 2} \ldots \ldots \ldots \ldots$ & $2.38 \pm 1.08$ & $0.74 \pm 0.07$ & $1.23 \pm 0.76$ \\
\hline 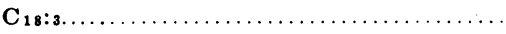 & $\ldots \ldots \ldots$ & $0.25 \pm 0.10$ & $\ldots \ldots \ldots$ \\
\hline $\mathbf{C}_{20}: 0 \ldots \ldots \ldots \ldots \ldots$ & $\ldots \ldots \ldots$ & $6.12 \pm 2.51$ & $\ldots \ldots \ldots$ \\
\hline
\end{tabular}

- N.D. = no detectable amount. 


\section{RESULTS}

Biological Variation. Table 2 gives the analyses of two collections of Myzus persicae from tomato (Lycopersicon esculentum); three of Macrosiphum euphorbiae (Thomas) - the pink form from $O x a l i s$ sp. and both the green and the pink forms from myrtle (Vinca sp.); and two of Pemphigus bursarius (Linnaeus) - one from lettuce roots (Lactuca sativa) and the other from a leaf gall on black poplar (Populus nigra). In general, when a given fatty acid averaged only 1 to 4 per cent of the total sample, the C.V. (coefficient of variation $=$ the standard deviation expressed as a percentage of the mean) ranged from 20 to 50 per cent; when a fatty acid made up 5 to 15 per cent of the sample, the C.V. ranged from 10 to 30 per cent; and when a fatty acid made up more than 20 per cent of the sample, the C.V. ranged from 2.5 to 9 per cent. As the C.V. for any constituent was inversely proportional to its mean, it would require large numbers of samples to show significant differences between those fatty acids that occur in low concentrations. The present investigation was not designed to test whether or not the amounts of the individual fatty acids differed significantly between different aphid species; standard deviations were not determined for each species, and only gross differences are considered significant. From the data in table 2, for example, it is questionable whether the amounts of $\mathrm{C}_{14}$ in Myzus persicae and Macrosiphum euphorbiae differ significantly. However, Pemphigus bursarius is considered to have significantly less $\mathrm{C}_{14}$ and significantly more $\mathrm{C}_{8}$ and $\mathrm{C}_{16}$ than either of the other two species.

Classes of Lipids in Macrosiphum barri. A collection of $\boldsymbol{M}$. barri from lettuce yielded approximately $173 \mathrm{mg}$ of crude lipid extract. From $16.71 \mathrm{mg}$ of this extract, placed on a silicic acid column, $12.58 \mathrm{mg}$ were recovered with chloroform and only $0.25 \mathrm{mg}$ with methanol. Thus, phospholipids made up about 1.5 per cent of the crude lipid extract. No further studies were made on them.

When $115.5 \mathrm{mg}$ of the crude lipid extract were run on the Florisil column (fig. 1), no significant amounts of sterol esters were eluted, but 80.8 per cent of the crude extract $(93.4 \mathrm{mg}$ ) was recovered as triglycerides. Approximately $1 \mathrm{mg}$ of sterols was recovered, but the diglycerides were barely detectable and there was little more of the monoglycerides than of the sterols. Free fatty acids made up only 2.8 per cent of the crude extract, as $3.3 \mathrm{mg}$ were recovered. The uneluted material, $12.8 \mathrm{mg}$ by difference, was soluble in 1:1 solution of methanol and water.

The triglycerides were transesterified by the methods described above, and the free fatty acids were esterified with diazomethane. The GLC analyses of these two fractions are shown in figure 2 , below an analysis of the unfractionated crude lipid extract. Table 3 gives the percentage of each fatty acid obtained in each of the three analyses. It is of special interest that the analysis of the free fatty acids showed a combined total of 56 per cent for oleic acid $\left(\mathrm{C}_{18: 1}\right)$ and linoleic acid $\left(\mathrm{C}_{18: 2}\right)$, whereas neither the glycerides nor the unfractionated lipids contained more than 7 or 8 per cent of the two acids combined. Although free fatty acids composed only 2.8 per cent of the crude lipid extract on an actual weight basis, 58 per cent of the linoleic acid and 16 per cent of the oleic acid in the crude extract occurred in the free form.

Host-Plant Influence on Fatty Acid Composition. Table 4 contains the results of analyses performed on apterae of Myzus persicae and Macrosiphum euphorbiae from various hosts. Considering the normal biological variation, there is no indication that the host plant appreciably affected the fatty acid composition of either of these 


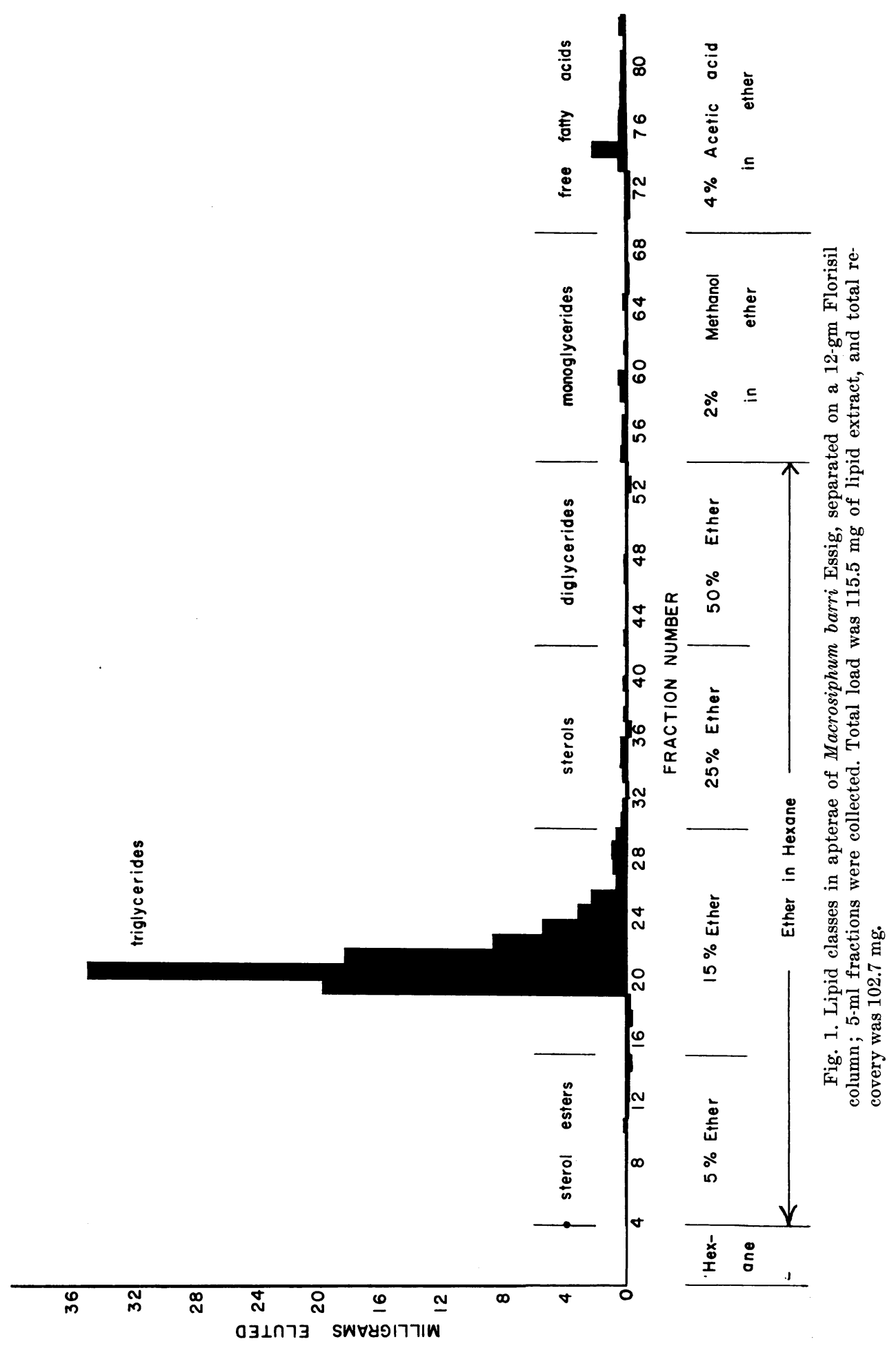


insects. Similarly, apterae of Pemphigus bursarius collected from lettuce roots did not differ appreciably in fatty acid composition from those collected from the black poplar galls. Although the figures are not shown in the table, apterae of Rhopalosiphum maidis (Fitch) from sorghum (Sorghum vulgare) had the same fatty acid composition, within the limits of biological variation, as those from johnsongrass (Sorghum halepense). Thus, it appears that the fatty acid composition of aphids may be a characteristic of the species rather than a manifestation of diet.

Physiological Age and Fatty Acid Composition. In some insects, the fat composition changes during the life cycle (Gilmour, 1961). To test aphids for such changes, Myzus persicae was analyzed at three different stages and three other species at two stages each. Table 5 shows that there was no difference between apterous adults of $M$. persicae and first- or second-instar nymphs. Nymphs were not separated from apterous adults in any of the other analyses. There was no significant difference between alatae and apterae of either Macrosiphum barri or $\boldsymbol{M}$. granarium (Kirby). However, in Rhopalosiphum fitchii (Sanderson) and in Myzus persicae, the fatty acid composition of alatae was appreciably different from that of the apterae analyzed. Alatae of $R$. fitchii had more $\mathrm{C}_{14}$ and less $\mathrm{C}_{16}$ than apterae. The reverse occurred in $M$. persicae: alatae had less $\mathrm{C}_{14}$ and more $\mathrm{C}_{16}$ than either nymphs or apterous adults. Thus, it appears that the various fat changes during aphid life cycles are perhaps characteristic for certain species rather than for aphids in general. These changes were probably not related to the host plant, for both Macrosiphum granarium and $R$. fitchii were reared on barley (Hordeum vulgare) and all three stages of Myzus persicae were collected from the same sugar beet plant.

Fatty Acid Compositions of Dif- ferent Aphids and Leafhoppers. Fatty acid compositions were determined for 21 species of aphids (tables 2, 6, 7, and 8 ) and six species of leafhoppers (table 9 ). The percentages of particular fatty acids varied widely between aphids and leafhoppers and between different species within each group. However, some patterns are evident. Aphids have relatively large amounts of $\mathrm{C}_{\mathbf{1 4}}$-from 33 to 87 per cent of the total fatty acid content-and small amounts of the $\mathrm{C}_{18}$ series-rarely more than 5 to 10 per cent of $\mathrm{C}_{18}, \mathrm{C}_{18: 1}, \mathrm{C}_{18: 2}$, and $\mathrm{C}_{18: 3}$ together. These statements apply to all aphid species analyzed except Rhopalosiphum nymphaeae (Linnaeus) in table 7 and Therioaphis maculata (Buckton) in table 8. All four species of Aphis in table 6 had relatively large amounts of $\mathrm{C}_{9}$, and so did Macrosiphum granarium and $M$. rosae (Linnaeus) in table 6 and Eriosoma lanigerum (Hausmann) in table 8. Four of the five species of Rhopalosiphum in table 7 had nearly as much $\mathrm{C}_{16}$ as $\mathrm{C}_{14}$, or more-a condition not observed in the other aphids analyzed. This might be a characteristic of the genus.

In contrast to aphids, leafhoppers (table 9) had only a small amount of $\mathrm{C}_{14}$ (usually less than 2 per cent) and a large amount of the $\mathrm{C}_{18}$ series-especially of $\mathrm{C}_{18: 1}$, which ranged from 29 to 63 per cent. Although not many species of leafhoppers were analyzed, there were some striking differences in fatty acid patterns. For example, Erythroneura elegantula Osborne, taken from grape (Vitis vinifera), had nearly 33 per cent $\mathrm{C}_{18: 3}$ and Empoasca filamenta DeLong, collected from gaillardia (Gaillardia pulchella), had 29 per cent. In contrast to this, four species, viz., Circulifer tenellus (Baker) from sugar beet, Hordnia circellata (Baker) from yeddo-hawthorn (Rhaphiolepis umbellata), Colladonus montanus (Van Duzee) from Brassica sp., and Macrosteles fascifrons (Stål) from celery (Apium graveolens), had little or no $\mathrm{C}_{18: 3}$. Figure 3 illustrates graphically the fatty 


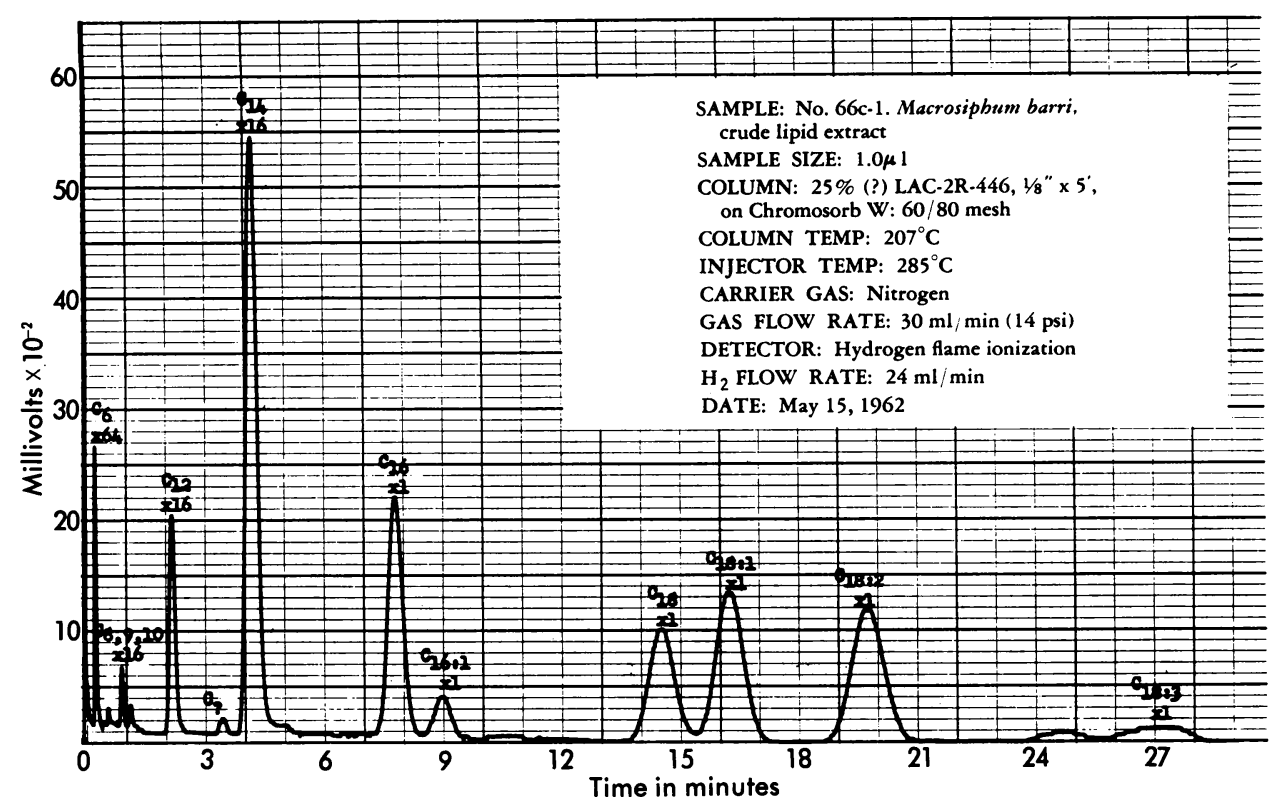

Fig. 2A. GLC chromatogram of lipids extracted from apterae of Macrosiphum barri Essig: crude lipid extract.

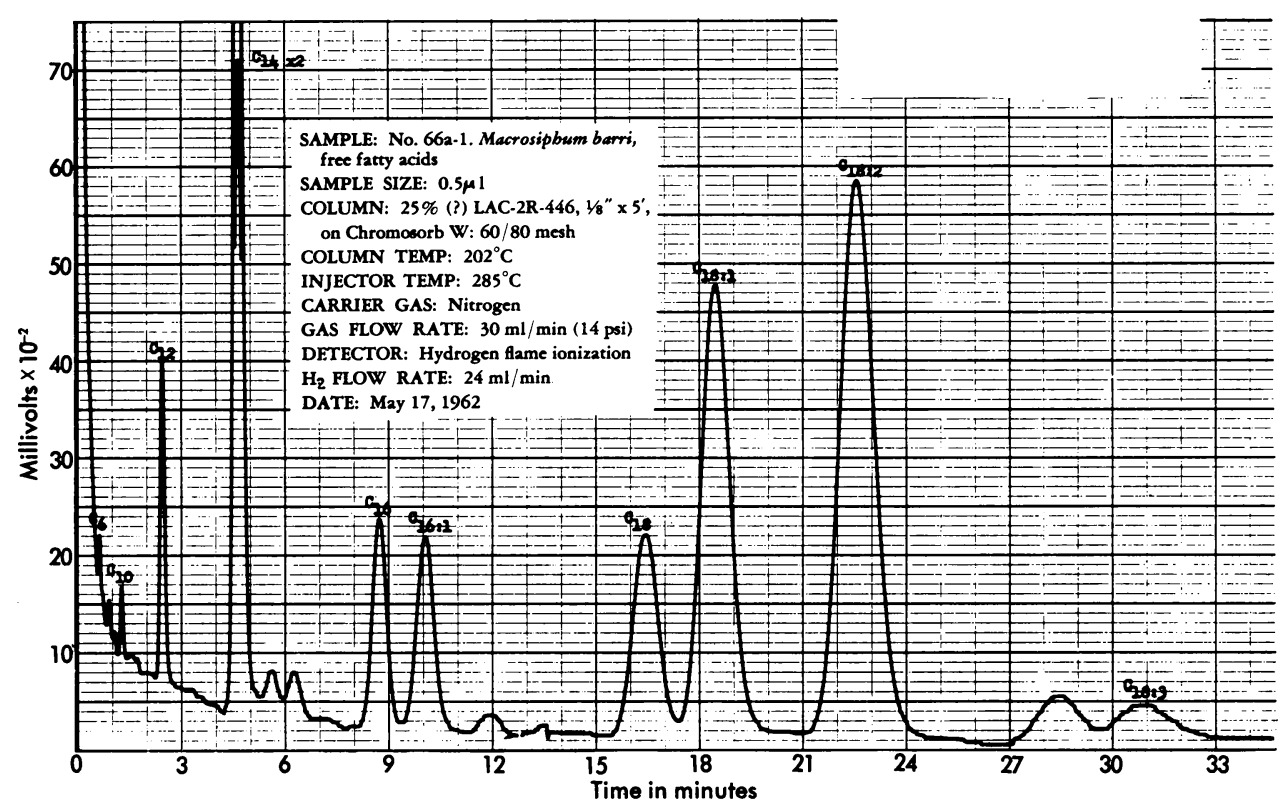

Fig. 2B. GLC chromatogram of lipids extracted from apterae of $M$. barri: free fatty acid fraction from Florisil column. 


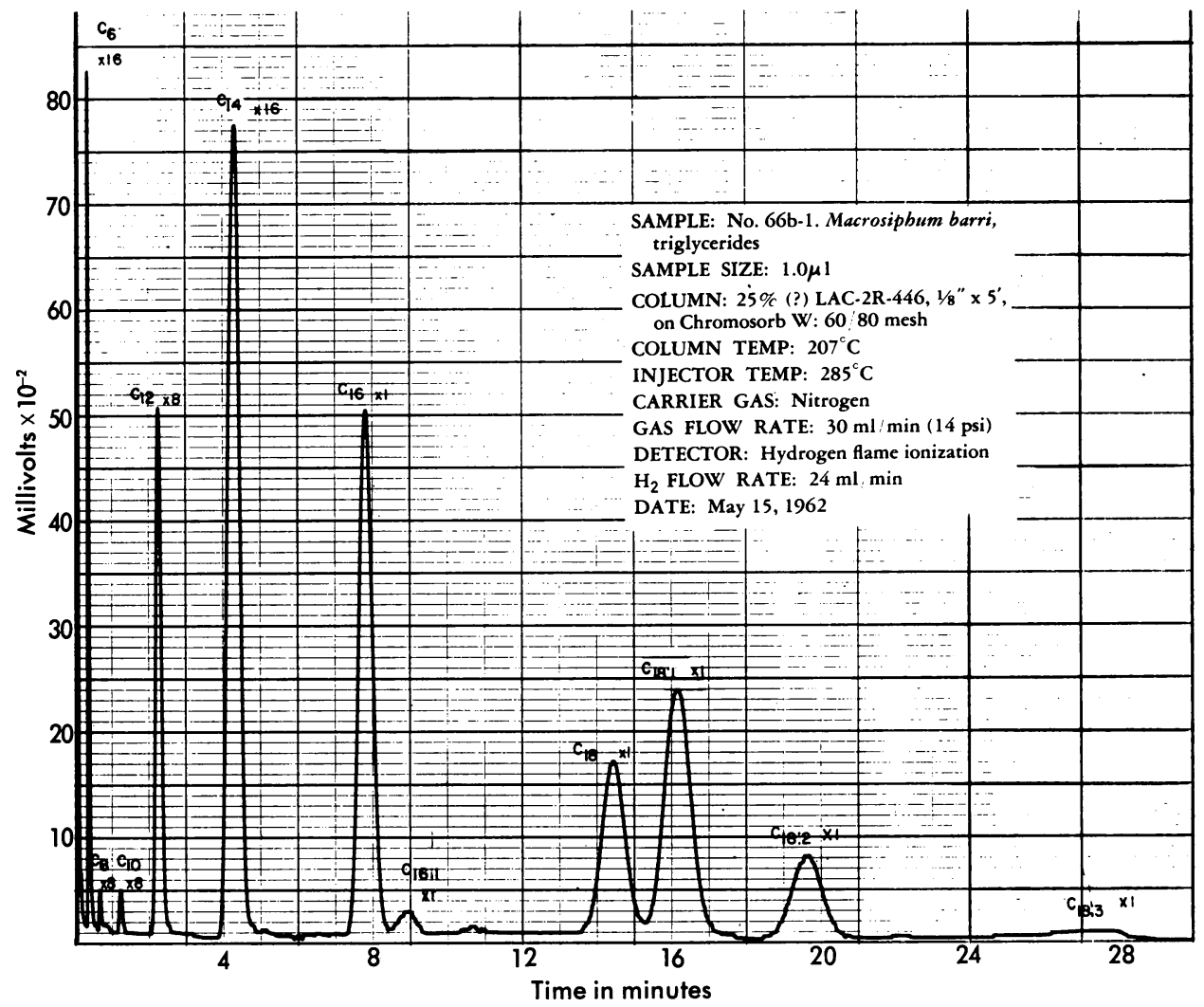

Fig. 2C. GLC chromatogram of lipids extracted from apterae of $M$. barri: triglyceride fraction from Florisil column.

TABLE 3

FATTY ACID COMPOSITION OF CRUDE AND FRACTIONATED LIPIDS FROM APTERAE OF Macrosiphum barri ESSIG REARED ON LETTUCE

\begin{tabular}{|c|c|c|c|}
\hline \multirow{2}{*}{ Fatty acid } & \multicolumn{2}{|c|}{ Lipid fraction } & \multirow{2}{*}{$\begin{array}{l}\text { Unfractionated } \\
\text { lipid extract }\end{array}$} \\
\hline & Free fatty acids & Triglycerides & \\
\hline & per cent & per cent & per cent \\
\hline $\mathrm{C}_{6} .$. & $\operatorname{Tr}^{*}$ & 5.62 & 4.27 \\
\hline $\mathrm{C}_{8} \ldots \ldots \ldots \ldots$ & $\operatorname{Tr}$ & 0.25 & 0.31 \\
\hline $\mathrm{C}_{9} \ldots \ldots \ldots \ldots$ & 0.51 & $\operatorname{Tr}$ & 1.42 \\
\hline $\mathbf{C}_{10} \ldots \ldots \ldots \ldots$ & 0.28 & 0.48 & 0.68 \\
\hline $\mathrm{C}_{12} \ldots \ldots \ldots \ldots$ & 2.56 & 11.15 & 12.54 \\
\hline $\mathrm{C}_{14} \ldots \ldots \ldots \ldots$ & 18.52 & 67.34 & 65.61 \\
\hline $\mathrm{C}_{18} \ldots \ldots \ldots \ldots$ & 4.42 & 4.95 & 2.97 \\
\hline $\mathrm{C}_{16: 1} \ldots \ldots \ldots \ldots \ldots \ldots$ & 5.25 & 0.26 & 0.64 \\
\hline 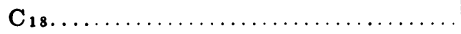 & 7.74 & 3.04 & 2.58 \\
\hline $\mathbf{C}_{18: 1} \ldots \ldots \ldots \ldots \ldots \ldots \ldots \ldots \ldots$ & 22.85 & 4.92 & 3.89 \\
\hline $\mathrm{C}_{18: 2 \ldots \ldots}$ & 33.20 & 1.99 & 4.13 \\
\hline $\mathbf{C}_{18: 3} \ldots \ldots \ldots \ldots \ldots \ldots \ldots \ldots \ldots \ldots \ldots \ldots \ldots$ & 2.78 & $\operatorname{Tr}$ & 0.35 \\
\hline 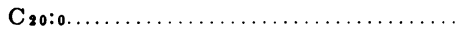 & 1.87 & $\mathbf{T r}$ & 0.57 \\
\hline
\end{tabular}

${ }^{*} \mathrm{Tr}=$ trace: not more than 0.15 per cent. 


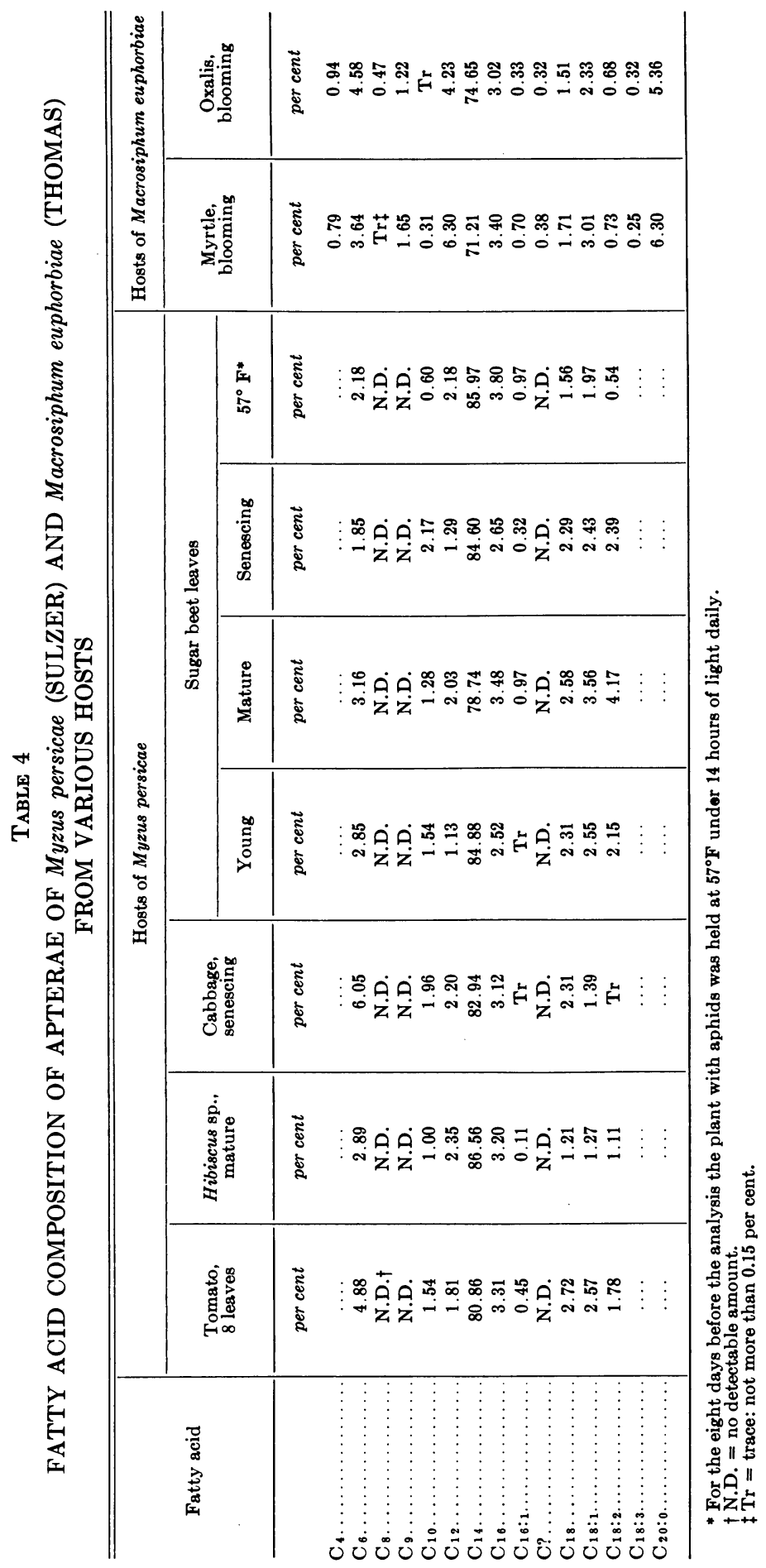




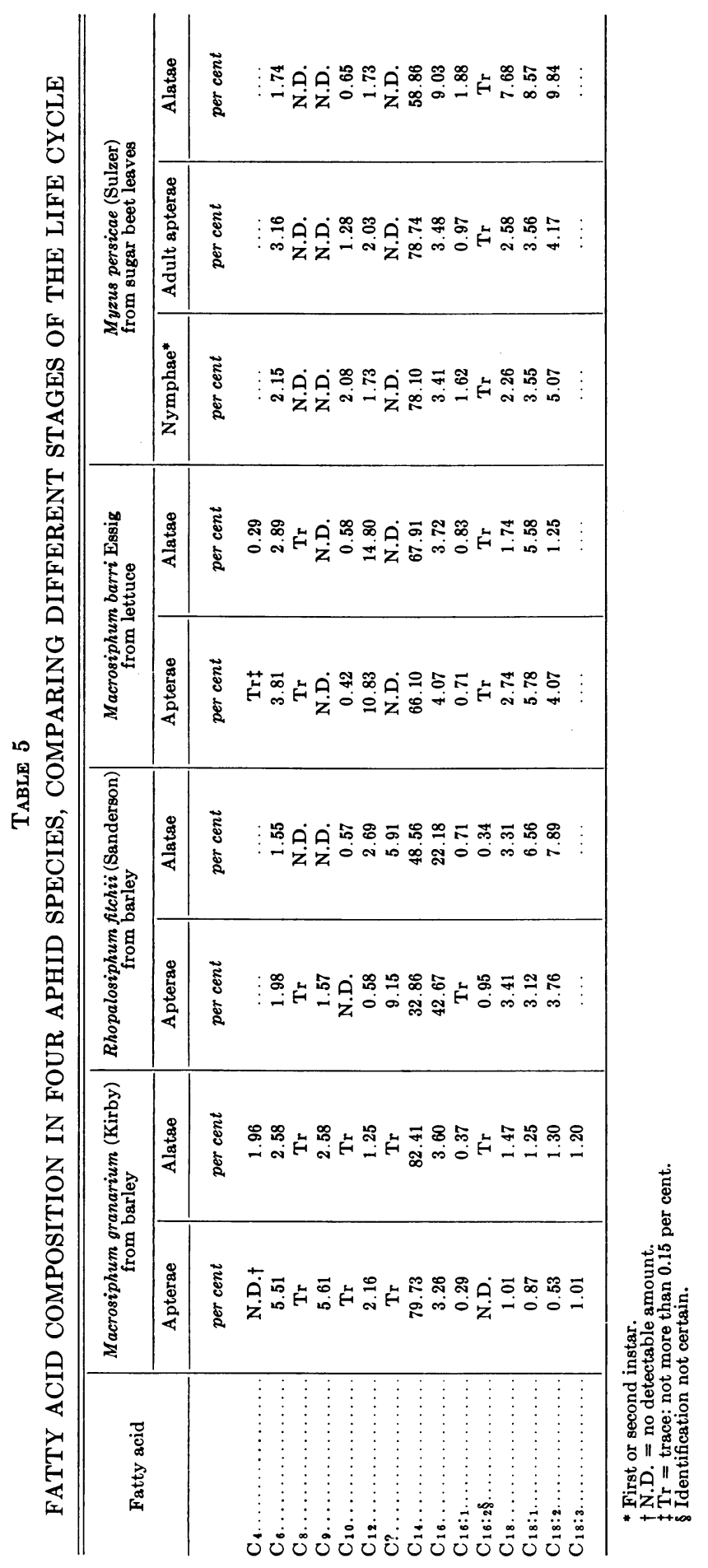




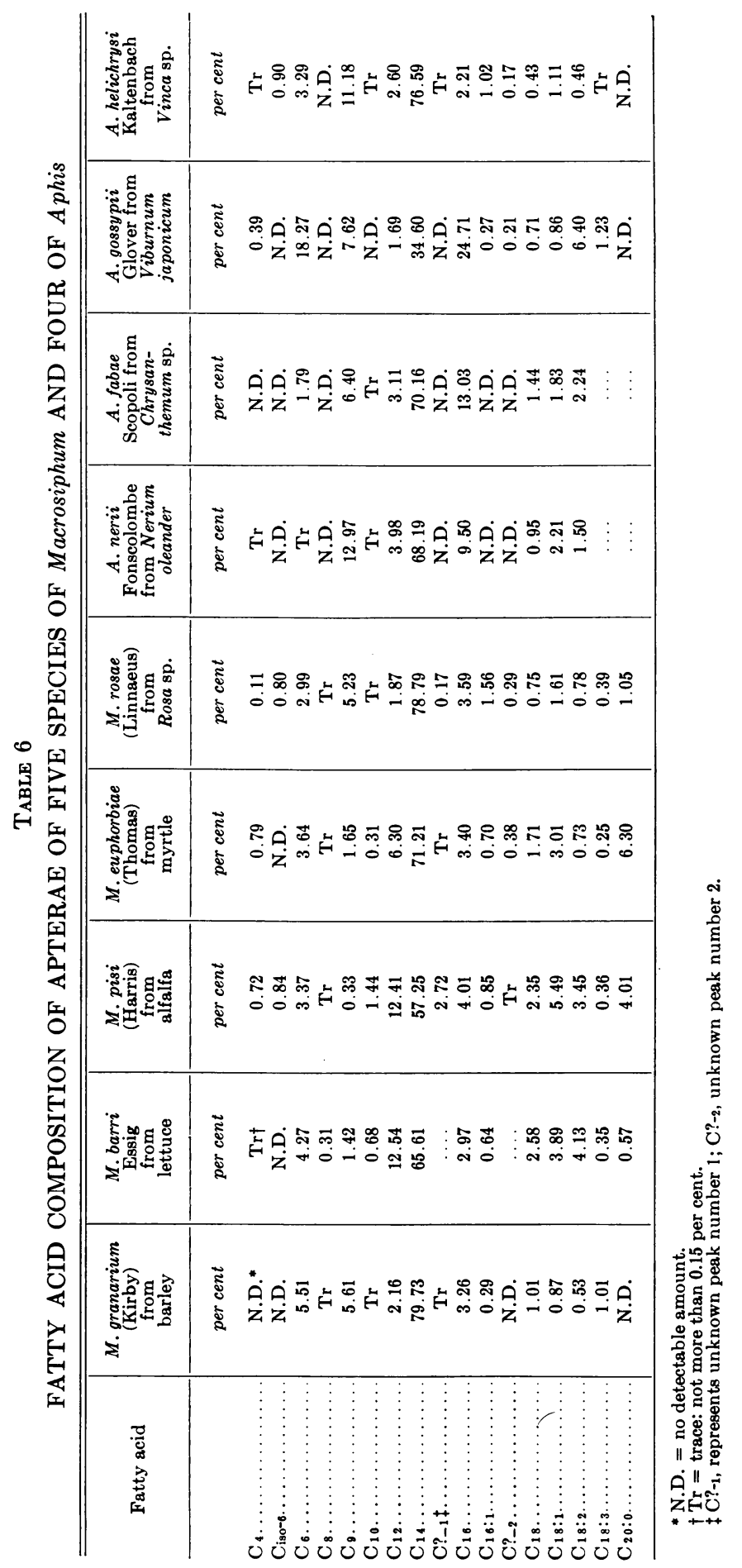


TABLE 7

FATTY ACID COMPOSITION OF APTERAE OF FIVE SPECIES OF Rhopalosiphum

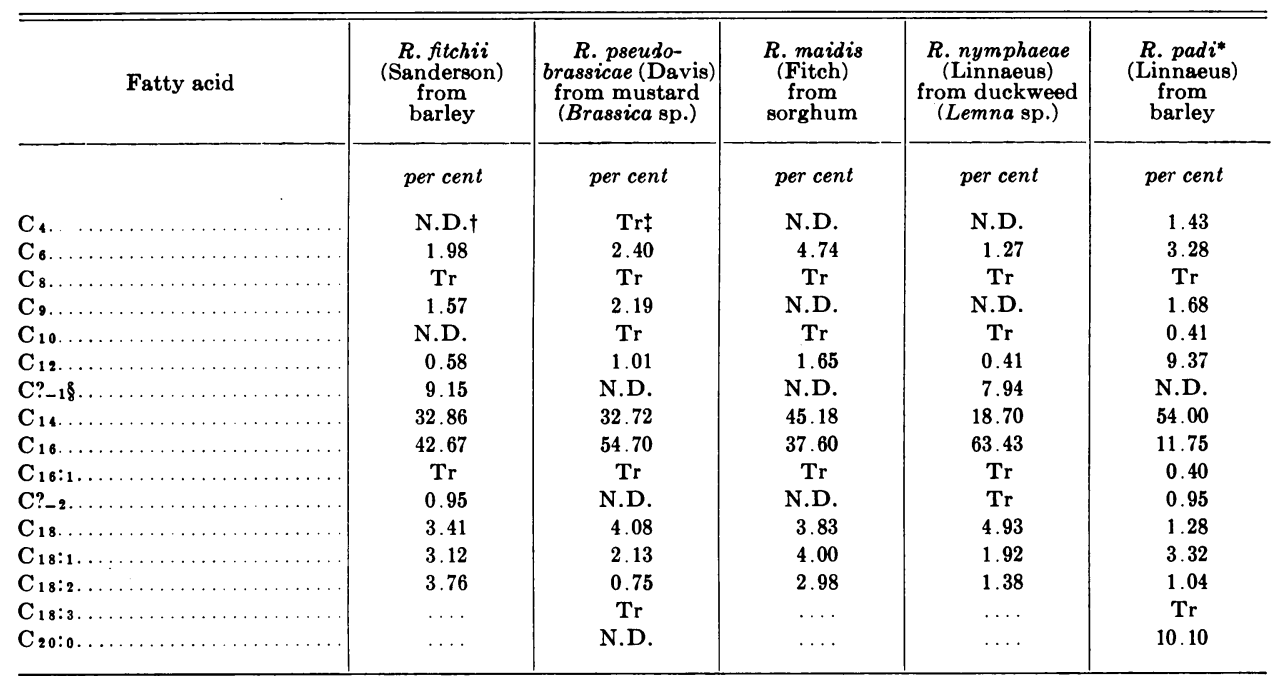

* Identification not certain; specimens are apparently in a complex composed of $R$. fitchii and $R$. padi (Richards, 1960). N.D. = no detectable amount.

$\pm \mathrm{Tr}=$ trace: not more than 0.15 per cent.

C?-1 represents unknown peak number 1 ; C?-2, unknown peak number 2 .

TABLE 8

FATTY ACID COMPOSITION OF APTERAE OF FIVE SPECIES OF APHIDS

\begin{tabular}{|c|c|c|c|c|c|}
\hline Fatty acid & $\begin{array}{c}\text { Eriosoma } \\
\text { lanigerum } \\
\text { (Hausmann) } \\
\text { from } \\
\text { flowering plum } \\
\text { (Prunus sp.) }\end{array}$ & $\begin{array}{c}\text { Toxoptera } \\
\text { aurantii } \\
\text { (Fonscolombe) } \\
\text { from } \\
\text { Camellia sp. }\end{array}$ & $\begin{array}{c}\text { Brevicoryne } \\
\text { brassicae } \\
\text { (Linnaeus) } \\
\text { from radish } \\
\text { (Raphanus } \\
\text { sativus) }\end{array}$ & $\begin{array}{c}\text { Hyolopterus } \\
\text { arundinis } \\
\text { (Fabricius) } \\
\text { from apricot } \\
\text { (Prunus } \\
\text { armeniaca) }\end{array}$ & $\begin{array}{c}\text { Therioaphis } \\
\text { maculata } \\
\text { (Buckton) } \\
\text { from } \\
\text { alfalfa }\end{array}$ \\
\hline & per cent & per cent & per cent & per cent & per cent \\
\hline $\mathrm{C}_{4}$. & 0.91 & $\operatorname{Tr}^{*}$ & & N.D.† & 1.71 \\
\hline $\mathrm{C}_{\text {lasu-6. }}$ & 0.24 & 2.04 & N.D. & N.D. & N.D. \\
\hline $\mathrm{C}_{8} \ldots \ldots$ & 1.39 & 0.55 & 1.23 & 4.68 & 9.29 \\
\hline $\mathrm{C}_{\mathbf{8}} \ldots \ldots \ldots \ldots$ & $\operatorname{Tr}$ & $\operatorname{Tr}$ & 0.14 & N.D. & 0.51 \\
\hline $\mathrm{C}_{9}$. & 12.38 & 2.27 & 0.23 & N.D. & 1.84 \\
\hline $\mathbf{C}_{10} \ldots \ldots$ & $\operatorname{Tr}$ & $\operatorname{Tr}$ & 2.67 & $\operatorname{Tr}$ & 1.12 \\
\hline $\mathrm{C}_{12} \ldots$ & 10.81 & 4.81 & 8.08 & 3.33 & 9.61 \\
\hline $\mathrm{C}_{14} \ldots \ldots$ & 56.36 & 62.39 & 60.00 & 50.85 & 38.31 \\
\hline$C_{16} \ldots$ & 13.62 & 22.08 & 19.44 & 36.82 & 11.74 \\
\hline $\mathrm{C}_{16: 1 \ldots}$ & 0.58 & $\operatorname{Tr}$ & 0.13 & 0.28 & 0.74 \\
\hline$C_{18} \ldots$ & 1.61 & 1.26 & 2.49 & 1.47 & 6.40 \\
\hline$C_{18: 1 \ldots}$ & 1.15 & 1.84 & 2.13 & 1.07 & 5.37 \\
\hline $\mathrm{C}_{18: 2 \ldots}$ & 0.48 & 0.74 & 1.31 & 1.50 & 8.59 \\
\hline $\mathrm{C}_{18: 3 \ldots}$ & 0.42 & $\operatorname{Tr}$ & 1.25 & N.D. & 1.68 \\
\hline $\mathrm{C}_{20}: 0 \ldots$ & N.D. & 2.25 & 0.87 & N.D. & N.D. \\
\hline
\end{tabular}

* $\mathrm{Tr}=$ trace: not more than 0.15 per cent.

$\dagger$ N.D. = no detectable amount. 
TABle 9

FATTY ACID COMPOSITION OF ADULTS OF SIX SPECIES OF LEAFHOPPERS*

\begin{tabular}{|c|c|c|c|c|c|c|c|}
\hline \multirow{2}{*}{ Fatty acid } & \multirow{2}{*}{$\begin{array}{c}\text { Erythroneura } \\
\text { elegantula } \\
\text { Osborne } \\
\text { from } \\
\text { grape }\end{array}$} & \multirow{2}{*}{$\begin{array}{c}\text { Empoasca } \\
\text { flamenta } \\
\text { DeLong } \\
\text { from } \\
\text { gaillardia }\end{array}$} & \multirow{2}{*}{$\begin{array}{c}\text { Circulifer } \\
\text { tenellus } \\
\text { (Baker) } \\
\text { from } \\
\text { sugar beet }\end{array}$} & \multirow{2}{*}{$\begin{array}{c}\text { Hordnia } \\
\text { circellata } \\
\text { (Baker) } \\
\text { from } \\
\text { yeddo- } \\
\text { hawthorn }\end{array}$} & \multirow{2}{*}{$\begin{array}{c}\text { Colladonus } \\
\text { montanus } \\
\text { (Van Duzee) } \\
\text { from } \\
\text { Brassica sp. }\end{array}$} & \multicolumn{2}{|c|}{$\begin{array}{l}\text { Macrosteles fascifrons } \\
\text { (Stal) from celery }\end{array}$} \\
\hline & & & & & & $\begin{array}{l}\text { Short- } \\
\text { winged }\end{array}$ & $\begin{array}{c}\text { Long- } \\
\text { winged }\end{array}$ \\
\hline & per cent & per cent & per cent & per cent & per cent & per cent & per cent \\
\hline $\mathrm{C}_{4}$.. & $\operatorname{Tr} \dagger$ & $\cdots$ & 0.13 & $\ldots$ & 0.97 & $\operatorname{Tr}$ & 4.31 \\
\hline $\mathrm{C}_{6} \ldots$ & $\mathbf{T r}$ & 0.02 & $\operatorname{Tr}$ & 0.19 & $\operatorname{Tr}$ & $\operatorname{Tr}$ & $\operatorname{Tr}$ \\
\hline $\mathrm{C}_{8} \ldots$ & N.D. & N.D. & $\operatorname{Tr}$ & $\mathbf{T r}$ & $\operatorname{Tr}$ & $\operatorname{Tr}$ & N.D. \\
\hline $\mathrm{C}_{10} \ldots$ & $\operatorname{Tr}$ & N.D. & 0.13 & $\operatorname{Tr}$ & $\mathbf{T r}$ & 0.02 & N.D. \\
\hline $\mathbf{C}_{12} \ldots \ldots \ldots \ldots \ldots \ldots$ & 0.07 & 0.25 & 0.36 & 1.25 & 0.26 & 0.31 & 0.31 \\
\hline $\mathbf{C}_{14} \ldots \ldots \ldots \ldots \ldots$ & 0.79 & 0.73 & 1.48 & 8.30 & 1.18 & 2.13 & 2.08 \\
\hline $\mathrm{C}_{16} \ldots \ldots \ldots$ & 14.73 & 23.11 & 18.52 & 36.13 & 16.50 & 20.59 & 17.73 \\
\hline $\mathrm{C}_{16: 1 \ldots}$ & 4.62 & 3.37 & 2.72 & 2.11 & 0.89 & 1.73 & 1.76 \\
\hline $\mathrm{C}_{18} \ldots$ & 1.81 & 1.47 & 3.14 & 1.84 & 2.40 & 3.59 & 3.50 \\
\hline$C_{18: 1}$ & 40.27 & 28.80 & 51.93 & 32.70 & 63.01 & 61.67 & 56.39 \\
\hline$C_{18: 2 .}$ & 3.88 & 12.69 & 20.94 & 16.52 & 14.79 & 10.32 & 13.73 \\
\hline $\mathrm{C}_{18: 3 \ldots}$ & 32.64 & 28.70 & 0.56 & 0.96 & 0.00 & 0.00 & 0.00 \\
\hline
\end{tabular}

* All species except Hordnia circellata are phloem feeders.

$\div$ Tr $=$ trace: not more than 0.15 per cent

$\ddagger$ N.D. $=$ no detectable amount.

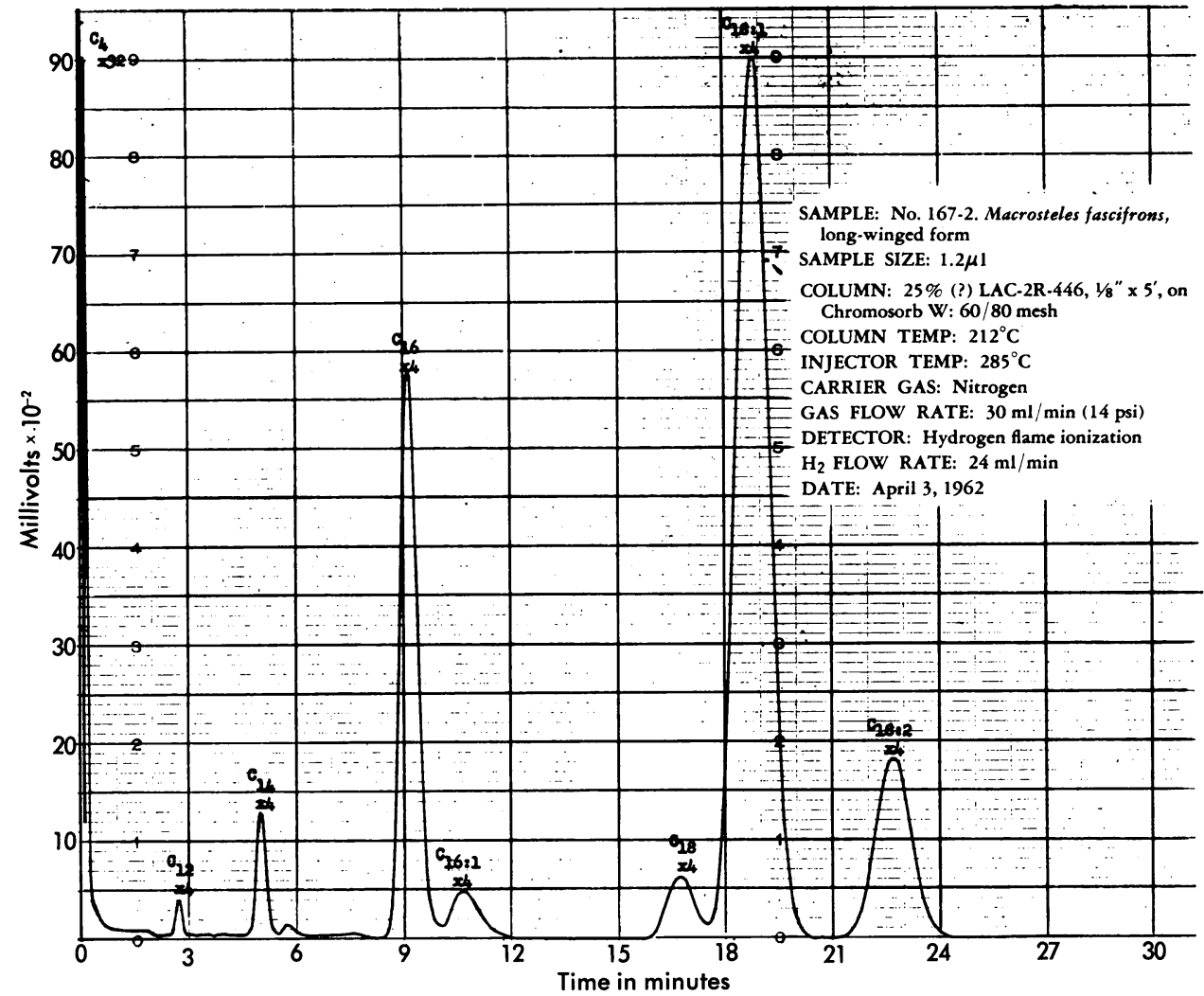

Fig. 3. GLC chromatogram of fatty acids extracted from adults of a typical leafhopper, Macrosteles fascifrons (Stål), long-winged form. Compare the peaks representing $\mathrm{C}_{14}$ and the $\mathrm{C}_{18}$ series with those in fig. $2 A$. 
acid pattern in the leafhopper $M$. fascifrons.

Occurrence of Fatty Acids in Honeydew and in Plant Juice. Airdried honeydew from Myzus persicae yielded $9.10 \mathrm{mg}$ of material extractable with chloroform: ethanol. This was $\mathbf{1 2 . 5 5}$ per cent of the $72.59 \mathrm{mg}$ collected over a three-day period. Honeydew of Therioaphis maculata yielded $10.7 \mathrm{mg}$ of ether-extractable material-15.88 per cent of the $67.5 \mathrm{mg}$ of honeydew. The pressed sugar beet leaves yielded 7.5 mg of ether-extractable material -0.042 per cent by weight of the $18 \mathrm{ml}$ of fresh juice.

Table 10 and figure 4 show the anal- yses of these extracts. Several unidentified peaks- $a, b, c, d, e$, and $f$-appear in the same locations in the three chromatograms and probably represent the same materials, presumably fatty acids. The most conspicuous difference in the three analyses was that honeydew of Myzus persicae contained very little $\mathrm{C}_{18: 2}$, although that fatty acid was the third most abundant in the beet-leaf juice and fourth in the honeydew of Therioaphis maculata. However, the total $\mathrm{C}_{18}$ series in $M$. persicae honeydew had a percentage midway between that in the other two analyses and higher than that in the plant juice.

TABLE 10

FATTY ACID COMPOSITION OF HONEYDEW AND OF SUGAR BEET LEAF JUICE

\begin{tabular}{|c|c|c|c|}
\hline \multirow[b]{2}{*}{ Fatty acid } & \multicolumn{2}{|c|}{ Honeydew from } & \multirow[b]{2}{*}{$\begin{array}{l}\text { Sugar beet } \\
\text { leaf juice }\end{array}$} \\
\hline & $\begin{array}{c}\text { Therioaphis } \\
\text { maculata } \\
\text { (Buckton) } \\
\text { on alfalfa }\end{array}$ & $\begin{array}{c}\text { Myzus } \\
\text { persicae } \\
\text { (Sulzer) } \\
\text { on sugar beet }\end{array}$ & \\
\hline & per cent & per cent & per cent \\
\hline $\mathrm{C}_{4} \ldots \ldots \ldots \ldots \ldots$ & $\ldots$ & N.D.* & Trt \\
\hline $\mathrm{C}_{6} \ldots \ldots \ldots \ldots \ldots \ldots$ & $\operatorname{Tr}$ & $\operatorname{Tr}$ & $\operatorname{Tr}$ \\
\hline $\mathbf{C}_{8} \ldots \ldots \ldots \ldots \ldots$ & 0.12 & 1.01 & $\operatorname{Tr}$ \\
\hline $\mathbf{C}_{\mathbf{g}} \ldots \ldots \ldots \ldots \ldots \ldots$ & 0.12 & 0.86 & 0.99 \\
\hline $\mathrm{C}_{10} \ldots \ldots \ldots \ldots$ & 0.28 & 1.12 & 0.67 \\
\hline $\mathrm{C} ?_{-\mathrm{a}} \ddagger \ldots \ldots \ldots$ & 0.23 & 0.23 & 0.72 \\
\hline C?-b. & 0.51 & 0.46 & 0.97 \\
\hline 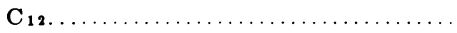 & 0.64 & 3.12 & 1.57 \\
\hline $\mathrm{C} \boldsymbol{r}_{-\mathrm{c}} \ldots \ldots \ldots \ldots \ldots \ldots \ldots \ldots$ & 0.43 & 0.76 & 1.22 \\
\hline $\mathrm{C}_{14} \ldots \ldots \ldots$ & 11.38 & 18.20 & 25.01 \\
\hline $\mathrm{C} ?_{-\mathrm{d}} \ldots \ldots \ldots \ldots \ldots$ & 4.64 & 2.65 & 1.95 \\
\hline $\mathrm{C} ?-\mathbf{e} \ldots \ldots \ldots$ & 2.29 & 0.67 & 1.80 \\
\hline $\mathrm{C}_{16} \ldots \ldots \ldots$ & 18.52 & 18.97 & 18.60 \\
\hline $\mathrm{C}_{16: 1} \ldots \ldots \ldots$ & 8.63 & 7.79 & 3.67 \\
\hline $\mathrm{C} ?_{-\mathbf{f}} \ldots \ldots \ldots$ & 1.85 & 0.63 & 3.16 \\
\hline $\mathrm{C}_{18} \ldots \ldots \ldots$ & 4.13 & 15.29 & 5.56 \\
\hline $\mathrm{C}_{18: 1} \ldots \ldots \ldots$ & 35.67 & 16.33 & 10.11 \\
\hline $\mathrm{C}_{18: 2 \ldots}$ & 9.32 & 1.03 & 11.66 \\
\hline $\mathrm{C}_{18}: \ldots \ldots \ldots \ldots \ldots \ldots \ldots \ldots \ldots \ldots$ & $\ldots$ & 9.70 & 9.14 \\
\hline 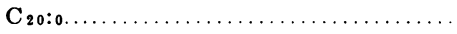 & $\ldots$ & 1.16 & 3.17 \\
\hline
\end{tabular}

* N.D. = no detectable amount.

$\dagger \mathrm{Tr}=$ trace: not more than 0.15 per cent.

F The unidentified peaks are indicated as C?-a, C?-b, and so forth. They had the same relative retention times in each of the three analyses. 


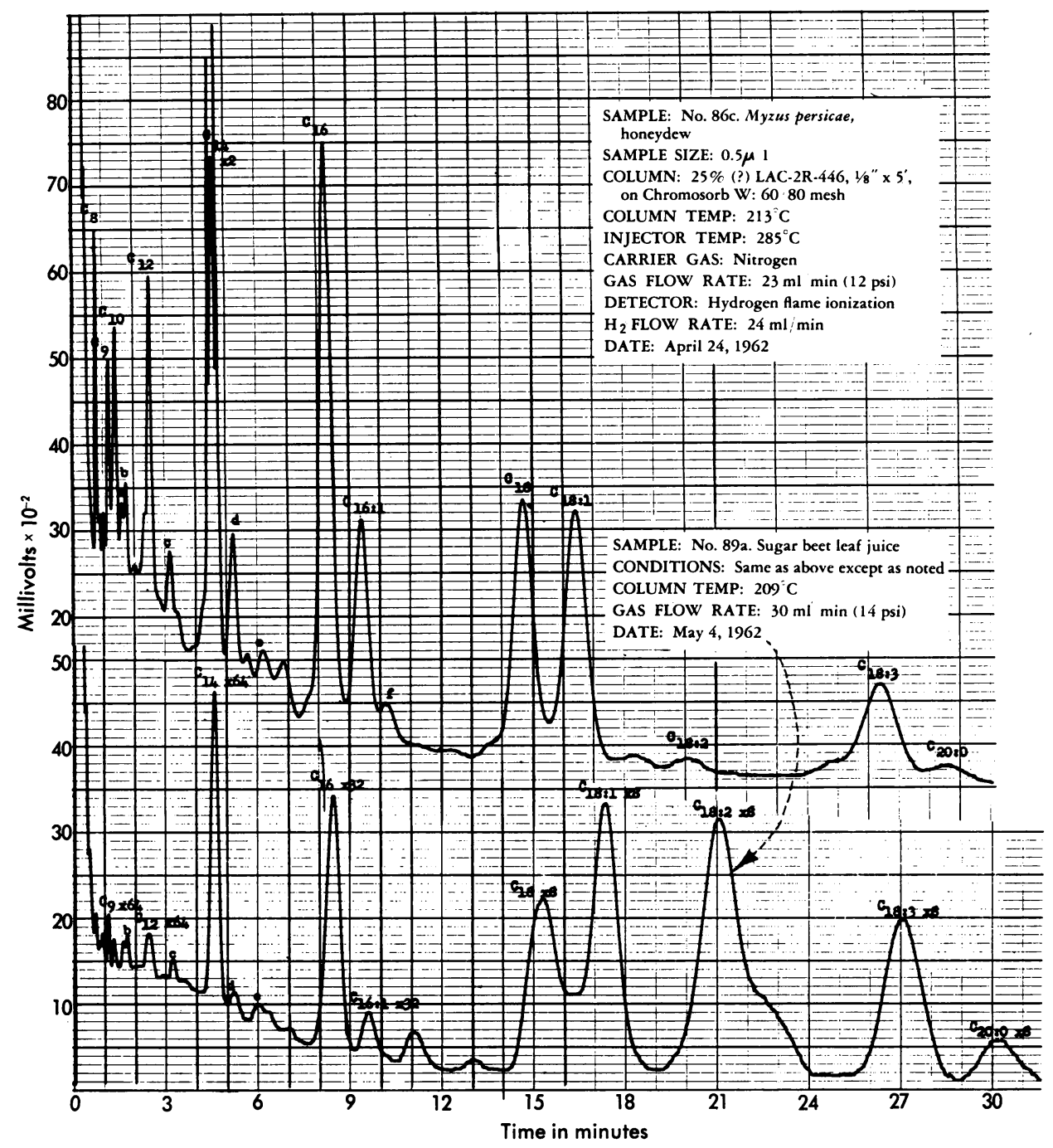

Fig. 4. GLC chromatograms showing the relationship of the fatty acids in green peach aphid honeydew and those in expressed sugar beet leaf juice. The relative retention times do not match exactly, as the column conditions were slightly different.

\section{DISCUSSION}

The possible taxonomic value of lipid studies such as these has been the subject of much debate in this laboratory. Although no great numbers of aphid species were analyzed, the data suggest evident patterns in the lipid relationships for certain species. The taxonomic value of such relationships cannot be assessed properly without more analyses. Meanwhile, these lipid relation- ships may have a limited taxonomic usefulness. For example, aphids collected from barley in the Salinas Valley, California, were tentatively identified as Rhopalosiphum fitchii, but an error in identification was suspected because the fatty acid analysis of this collection was in such disharmony with analyses of other collections of $R$. fitchii. Winged adults of the Salinas 
collection identified by the California State Department of Agriculture were returned with the label Rhopalosiphum padi (Linnaeus) complex. Richards' (1960) discussion of this complex corroborates the evidence of the lipid studies that two species are involved.

Gilmour (1961) cited several examples to illustrate that the composition of fats in insects is influenced to a certain extent by diet. In general, highfat diets influence body-fat composition to a greater extent than do low-fat diets. The approximate fat composition of most leafy vegetables is only 0.2 to 0.4 per cent of the fresh weight (Peterson and Strong, 1953). Such a low percentage implies that the fatty acid compositions even of unrelated hosts cannot differ so much that they would alter the body fat of aphids appreciably-even if one assumes that an aphid's body-fat composition is dependent on its diet. Moreover, a comparison of the analyses for two aphids from the same host shows that such an assumption is not completely true: Therioaphis maculata in table 8 and Macrosiphum pisi (Harris) in table 6, both collected from Vernal alfalfa (Medicago sativa), had different fatty acid patterns.

The question whether aphids require any lipid materials in their diets cannot be answered definitely until techniques for artificial feeding of aphids are perfected. However, the present study suggests that aphids require at least some lipids. Myzus persicae may require some linoleic acid in its diet, because this fatty acid was abundant in sugar beet leaf juice but virtually absent from the honeydew emitted by aphids fed on sugar beet leaves. The close qualitative agreement in other respects between the two chromatograms of figure 4 indicates that the plant juice analyzed was fairly representative of the aphids' diet, though leaf juice was analyzed instead of phloem sap. Only three of 11 extracts from $M$. persicae apterae (tables 2, 4, and 5) contained as much as 4 per cent linoleic acid, but in extracts from alatae (table 5), $M$. persicae had 9.84 per cent linoleic acid and Rhopalosiphum fitchii 7.89 per cent. The highest percentage of linoleic acid in any extract from apterae was 8.59 per cent in Therioaphis maculata (table 8), whose honeydew also had a high content-9.23 per cent.

If, indeed, the green peach aphid requires $\mathrm{C}_{18: 2}$, the means by which it acquires this material should be of great interest. Zimmermann's (1960) review of the transport of organic substances in phloem does not mention lipids. Ziegler (1956) reported phosphatides in sieve tube exudates of several trees in concentrations below $0.1 \mathrm{mg} / \mathrm{ml}$ but considered these nonmobile. Further studies are needed on the lipids in honeydew and on the form in which lipids occur in plant juice, especially in sieve tube exudates.

\section{SUMMARY}

The fatty acid composition was determined for 21 species of aphids and six species of leafhoppers. In addition, the classes of lipids extracted from the aphid Macrosiphum barri were separated by column chromatography. Nearly all of the fatty acids in $\boldsymbol{M}$. barri were in the form of triglycerides, and the free fatty acids made up less than 3 per cent of the total lipid content. In general, aphids had a high proportion of $\mathrm{C}_{14}$ and a low proportion of the $\mathrm{C}_{18}$ series, and the reverse was found for leafhoppers. The fatty acid composition of an aphid appears to be a species characteristic, not appreciably influenced by the host plant. It changed with the stage of development in some instances but not in others. Fatty acids were found in the honeydew analyzed for two species of aphids. Their relative proportions in the honeydew of the green peach aphid and in the juice of its host plant suggest that linoleio:acid may be required in the diet of that aphid. 


\section{LITERATURE CITED}

CARroll, K. K.

1961. Separation of lipid classes by chromatography on florisil. Jour. Lipid Res. 2: 135-41

DADD, R. H.

1960. The nutritional requirements of locusts. I. Development of synthetic diets and lipid requirements. Jour. Insect Physiol. $4: 319-47$.

EsAU, K., R. NAMBA, and E. A. RASA

1961. Studies on penetration of sugar beet leaves by stylets of Myzus persicae. Hilgardia 30 (17) :517-29.

Folch, J., M. Lees, and G. H. Sloane-Stanley

1957. A simple method for the isolation and purification of total lipids from animal tissue. Jour. Biol. Chem. 226:497-509.

Fraenkel, G., and M. Blewett

1946. Linoleic acid, vitamin $E$ and other fat-soluble substances in the nutrition of certain insects, Ephestia kuehniella, E. elutella, E. cautella and Plodia interpunctella (Lep.). Jour. Expt. Biol. 22:172-90.

Friend, W. G.

1958. Nutritional requirements of phytophagous insects. Ann. Rev. Ent. 3:57-74.

GILMOUR, DARCY

1961. The biochemistry of insects. Academic Press, New York and London. 343 pp.

Giral, Francisco

1946. Fats of insects. V. Sphenarium purpurascens Charpentier. Jour. Biol. Chem. 162:61-63.

Hilditch, Thomas Percy

1956. The chemical constitution of natural fats. 3rd ed. John Wiley \& Sons, Inc., New York, and Chapman \& Hall, Ltd., London. 664 pp.

House, H. L.

1961. Insect nutrition. Ann. Rev. Ent. 6:13-26.

KENNEDY, J. S., and T. E. MiTTLER

1953. A method of obtaining phloem sap via the mouth-parts of aphids. Nature [London] $171: 528$.

LAMB, K. P.

1959. Composition of the honeydew of the aphid Brevicoryne brassicae (L.) feeding on swedes (Brassica napobrassica DC.). Jour. Insect Physiol. 3:1-13.

Levinson, Z. H., and E. D. BergmanN

1957. Steroid utilization and fatty acid synthesis by larva of the housefly Musca vicina Macq. Biochem. Jour. 65:254-66.

Maltais, J. B., and J. L. Auclair

1952. Occurrence of amino acids in the honeydew of the crescent-marked lily aphid, Myzus circumflexus (Buck.). Canad. Jour. Zool. $30: 191-93$.

MitTler, T. E.

1953. Amino-acids in phloem sap and their excretion by aphids. Nature [London] 172:207.

1958. Studies on the feeding and nutrition of Tuberolachnus salignus (Gmelin) (Homoptera: Aphididae). II. The nitrogen and sugar composition of ingested phloem sap and excreted honeydew. Jour. Expt. Biol. 35:74-84.

MitTler, T. E., and R. H. DADD

1962. Artificial feeding and rearing of the aphid Myzus persicae (Sulzer), on a completely defined synthetic diet. Nature [London] $195: 404$.

Peterson, W. H., and F. M. Strong

1953. General biochemistry. Prentice-Hall, Inc., New York. 469 pp.

RICHARDS, W. R.

1960. A synopsis of the genus Rhopalosiphum in Canada (Homoptera: Aphididae). Canad. Ent. Suppl. 13. $51 \mathrm{pp}$.

Tietz, A.

1961. Fat synthesis in cell-free preparations of the locust fat-body. Jour. Lipid Res. 2:182-87.

Timon-David, JEAN

1928. Contribution à la connaissance des graisses d'insectes: le beurre de pucerons du térébinthe. Compt. Rend. Acad. des Sci. [Paris] 186:104-06.

VAN HANDEL, EMILE

1959. Separation and chemical assay of lipid classes. Jour. Amer. Oil Chem. Soc. 36:294-97.

VAN HANDEL, Emile, and Patrick T. M. Lum

1961. Sex as regulator of triglyceride metabolism in the mosquito. Science $134: 1979-80$. 
voN DEHN, MAdELEINE

1961. Untersuchungen zur Ernährungsphysiologie der Aphiden. Die Aminosäuren und Zucker im Siebröhrensaft einiger Krautgewächsarten und im Honigtau ihrer Schmarotzer.

WATERHouse, D. F. Ztschr. f. Vergleich. Physiol. 45:88-108.

1957. Digestion in insects. Ann. Rev. Ent. 2:1-18.

Wren, J. J., and H. K. Mitchell

1959. Extraction methods and an investigation of Drosophila lipids. Jour. Biol. Chem. 234 :2823-28.

ZEBE, E. C., and W. H. MCShaN

1959. Incorporation of $\mathrm{C}^{14}$-acetate into long chain fatty acids by the fat body of Prodenia eridania (Lep.). Biochim. et Biophys. Acta 31:513-18.

ZIEGLER, HUBERT

1956. Untersuchungen über die Leitung und Sekretion der Assimilate. Planta 47:447-500. ZimMERMANN, MARTIN H.

1960. Transport in the phloem. Ann. Rev. Plant Physiol. 11:167-90.

In order that the information in our publications may be more intelligible it is sometimes necessary to use trade names of products or equipment rather than complicated descriptive or chemical identifications. In so doing it is unavoidable in some cases that similar products which are on the market under other trade names may not be cited. No endorsement of named products is intended nor is criticism implied of similar products which are not mentioned. 

The journal HILGARDIA is published at irregular intervals, in volumes of about 650 to 700 pages. The number of issues per volume varies.

Single copies of any issue may be obtained free, as long as the supply lasts; please request by volume and issue number from:

\section{Agricultural Publications \\ University Hall \\ University of California \\ Berkeley 4, California}

The limit to nonresidents of California is 10 separate titles. The limit to California residents is 20 separate titles.

The journal will be sent regularly to libraries, schools, or institutions in one of the following ways:

1. In exchange for similar published material on research.

2. As a gift to qualified repository libraries only.

3. On a subscription basis $-\$ 7.50$ a year paid in advance. All subseriptions will be started with the first number issued during a calendar year. Subscribers starting during any given year will be sent back numbers to the first of that year and will be billed for the ensuing year the following January. Make checks or money orders payable to The Regents of The University of California; send payment with order to Agricultural Publications at above address. 